\title{
Society and Weapons: Civil Law, Criminal Law, and Historiographical Aspects
}

\begin{abstract}
Kofanov Andrii
Legal Advisor to the Council of Europe Programme "Decentralization and Territorial Consolidation in Ukraine”, PhD of Juridical Sciences, Associate Professor, Professor of Department of Forensic Support and Forensic Expertise of the National Academy of Internal Affairs, Kiev, Ukraine ORCID ID 0000-0002-5242-2518_kofanov_andrey@ukr.net
\end{abstract}

\section{Pavlovska Nataliia}

PhD of Juridical Sciences, Associate Professor, Professor of Department of Civil Law and Process of the National Academy of Internal Affairs, Kiev, Ukraine ORCID ID 0000-0003-3311-0364 wwwpav@gmail.com

\section{Tereshchenko Yuliia}

PhD of Juridical Sciences, Professor of Criminal Law Disciplines and Operative and Investigative Activities of the Precarpathian Department of the

National Academy of Internal Affairs, Kyiv, Ukraine ORCID ID0000-0002-5353-0887_vladysikter@ukr.net

\section{Svoboda Eugenia}

PhD of Juridical Sciences, Associate Professor, Professor of Department of Forensic Support and Forensic Expertise of the National Academy of Internal Affairs, Kiev, Ukraine ORCID ID 0000-0002-8639-8333 jeechka@ukr.net

\section{Filipova Natalia}

Asistant of the Departament of Law of Prydunai Branch of Private Jointstock Company "Higher Educational Institution of Interregional Academy of Personnel Management», Izmail, Ukraine ORCID ID 0000-0001-7132-8343 filinatalja2310@gmail.com

\footnotetext{
Abstract

Weapons per se are a source of increased danger; their spread in the society is influenced by various economic, moral and other important factors, to be topped by such key factor as the Law of Ukraine "On Weapons". Great importance on the part of Ukrainian government authorities and civil-society organizations is attached in this context to the development and implementation of the national doctrine of supporting the
} 
security of man, society and the State, as well as to improving the efficiency and effectiveness of legislative, law enforcement and human rights activities.

Keywords: Constitution of Ukraine, society, weapons, civil law, criminal law, historiographical aspects, Law of Ukraine "On Weapons".

Introduction The current state of the Ukrainian society requires the development of an efficient and pragmatic concept of the State formation, therefore, the issues related to building a sovereign, democratic, social and law-based State to ensure comprehensive protection of human and civil rights and freedoms are acquiring particular relevance, novelty, and practical significance these days (Articles 1, 3, 17, 19 of the Constitution of Ukraine) [1]. For the first time during the last three centuries of building Ukraine's statehood, the 1996 Constitution of Ukraine formulated a human-centric conceptual basis on which the State and society's position towards the individual and the citizen is founded. For example, Article 3 of the Ukrainian State's Organic Law stipulates that “An individual, his life and health, honor and dignity, inviolability and security shall be recognized in Ukraine as the highest social value. Human rights and freedoms, and guarantees thereof shall determine the essence and course of activities of the State. The State shall be responsible to the individual for its activities. Affirming and ensuring human rights and freedoms shall be the main duty of the State" [1]. Ukraine's Organic Law thus defines the doctrinal framework for prioritized development of theory and methodology, diplomacy, and cultural studies, policies and strategies in the activities pursued both by the legislative, executive, judicial branches and by civil-society organizations.

Implementing constitutional provisions in education, science and practice of the Ukrainian statehood is relevant, since the country's domestic situation has been characterized by complexities and contradictions in the process of developing, building and ensuring the State doctrine of individual, public and national safety [2, 3].

Emergence of a new society where the relationships of private, communal and State property are to prevail necessarily requires a new approach towards protection of such property, individual rights, along with protecting the human beings themselves, their life, honor and dignity against criminal encroachments.

New patterns of relationships form a legal framework for the protection of individual and his/her interests, which is a positive phenomenon. However, against this positive backdrop, certain negative phenomena are emerging, such as the rise in crime, slackness in 
the operation of law enforcement agencies that fail to keep the pace with the ever growing negativity. In this situation, the public harbors a natural desire for self-defense, including the use of weapons or other means of combating crime.

Article 27.2 of Ukraine's Constitution declares that "Everyone shall have the right to protect his life and health, and lives and health of other people against unlawful encroachments" [1]. This constitutional provision has been enshrined in other areas of law. For example, the Criminal Code of Ukraine in its Article 15 "Necessary Defense" expressly refers to an actual possibility for an individual to employ a weapon when using this institute. One of the ways to protect the above-mentioned human rights is an individual's right to possess, carry, use and employ weapons. To a certain extent, the right of citizens to own weapons contradicts the right of other citizens to life and health, since it potentially entails deadly use of such weapons against other citizens. Weapons, especially firearms, when directed against a person, are capable not only of causing a certain harm to human health, but also of taking the life of the person against whom they are applied. The internal affairs authorities thus bear statutory responsibility for performing both licensing (granting licenses to own, use, and store weapons) and monitoring functions (verifying the legality of owning weapons, collecting information on the instances of deadly force used against humans and assessing the lawfulness of such use of firearms, etc.) functions. Furthermore, the internal affairs authorities maintain records of firearms held by both legal entities and citizens residing within Ukraine.

In the independent Ukraine, the legal regulation of firearms circulation began with the adoption on $06 / 17 / 1992$ by the Verkhovna Rada of Ukraine of the Resolution "On Titles to Certain Types of property" whose Appendix 2 sets out a special procedure for acquisition by citizens of titles to specific types of property.

This special procedure for title acquisition applies to smooth-bore and rifled hunting weapons, gas pistols or revolvers and cartridges thereto filled with tear-inducing or irritating substances, edged weapons, as well as pneumatic weapons whose bullet velocity exceeds 100 mps and caliber $-4.5 \mathrm{~mm}$. The next step in this field was the adoption by the Cabinet of Ministers of Ukraine on 10/12/1992 of the Resolution “On Licensing System" that directly addresses the firearms circulation in Ukraine. The Order No. 164 adopted on 25 March 1993 by the Ministry of Internal Affairs (MIA) of Ukraine approved the guidelines "On the 
procedure for manufacture, purchase, storage, keeping records, transportation and use of firearms, ammunition thereto, and explosives" (no longer effective under the new Order No. 622 adopted by the Ministry of Internal Affairs of Ukraine on 08/21/1998). In this country, social relations associated with firearms circulation are currently regulated by 89 legal acts (including laws, orders, resolutions, etc.). Regretfully, the key piece of legislation — the Law of Ukraine "On Firearms" — is missing among them. The expediency of adopting this Law was mentioned way back in the Regulations "On the 'Personalized Firearms' Presidential Decoration" adopted on 04/29/1995. Adopting this law and conducting this research are also relevant in view of the fact that, with the adoption of the Constitution of Ukraine in 1996, a new impetus was given to building a democratic, law-based State whose key objective and mission are to assert, safeguard and protect human and citizen's rights and freedoms against unlawful encroachment. Addressing this task entails resolving a number of complex political, economic, social and legal problems, as the actual state of affairs in the country and society is still far from meeting the dictates of the time.

It is well known that, over the last decade, the global community has been experiencing a certain boom of "armed" crime.

The underworld uses various weapons in its criminal activities, such as firearms, edged, projectile, pneumatic, tear gas, electric and other weapons.

Summarized findings of our experimental, sociological and historiographical studies (1930-2003) $[4,5,6]$, statistics from the government institutions, legislative, executive and judicial authorities indicate that the complexity of addressing this problem is further exacerbated by the lack in Ukraine of a clear and efficient mechanism of legislative support for the circulation of firearms, at the same time being characterized by manifestations of latent illicit trafficking in these weapons as a real threat to rights and freedoms of man, society and the State $[5,7,8,9,10]$.

Our generalized comparative analysis of modern criminal statistics on arms trafficking in the country shows that, in the course of special operations conducted by law enforcement units in Ukraine, 23,419 firearms were seized from illicit traffic between 1992 and 2000 only. Between 1992 and 1999, more than 1,491 firearms were stolen in Ukraine. 8,952 crimes were committed with these weapons throughout Ukraine in 1992-1999 [4].

Forestry statistics, however, indicate that, as of 01/01/2003, about 480 thousand 
hunters were registered in Ukraine, with the total area of hunting grounds covering $48 \mathrm{~m}$ hectares, of which $37 \mathrm{~m}$ hectares $(77.4 \%$ of all Ukraine's hunting grounds) were made available to the Ukrainian Society of Hunters and Fishermen, 6.6m hectares (13.8\%) - to the State Forestry Committee's enterprises, $1.1 \mathrm{~m}$ hectares $(2.3 \%)$ - to the Society of Military Hunters and Fishermen, 3.1m hectares $(6.5 \%)$ — to more than 90 other users.

More than 5.3 thousand people are currently employed in Ukraine's hunting sector, including 560 hunters and 3,790 full-time game wardens [11].

As of 01/01/2000, 668,579 firearms owners were registered by the Ukrainian MIA's licensing system, who currently hold 754,694 own firearms.

Furthermore, findings of a generalized study conducted by a group of authors indicate that, between 1991 and 1995 only, in addition to smooth-bore hunting firearms, citizens of Ukraine purchased from business entities (shops, companies) 9,000 special-purpose smoothbore and combat firearms whose performance is non-compliant with the standards and criteria established for hunting weapons in Ukraine or globally, and which, under the legal rules and statutory methodology, could not and should not have been imported and sold in this country as smooth-bore hunting weapons $[12,13,14]$.

The police currently keep records of 116,000 special devices (gas sprays, pistols and revolvers) that are held by Ukrainian citizens and are allowed by the government only to individuals over 18 years of age, subject to the positive opinion of a relevant medical board and a licensing body decision.

According to the MIA of Ukraine, as of 12/01/2002, almost 25 thousand firearms were seized from the criminals - enough to arm 17 regiments, and almost four thousand kilograms of explosives - enough to manufacture more than five thousand anti-personnel mines.

Compared to 1997, the number of firearm murders dropped by $34 \%$ in 2002; nevertheless, there are still lots of weapons in circulation.

This is evidenced by a recent report of the Ukrainian MIA about a record arsenal of weapons stolen by the underworld for its criminal purposed from the government in the Kirovohrad Oblast. About 200 pistols and submachine guns, 44 anti-tank grenade launchers, $75 \mathrm{~kg}$ of TNT, and more than 17 thousand rounds were taken there from a guarded weapons depot by the criminals.

In 2002, police officers in the Rivne Oblast detained a group of gangsters whose 
hiding place was a storage for a machine gun, pistols with silencers, hand grenades, sawn-off hunting shotguns, ammunition, masks, shackles, poison ampoules.

Crime statistics from many countries show that the key negative trends in the "armed" crime manifestations include: 1) high social tensions prevailing in many regions across the globe, where weapons circulate (Afghanistan, Chechnya, Iraq, etc.); 2) a fairly high percentage of crimes committed with the use of firearms, mines and explosives; 3) a rapidly expanding range of various types of weapons used for criminal purposes (portable, maneuverable, simply designed and widely available weapons for private use, such as firearms, edged, projectile, pneumatic, tear gas, electric weapons); 4) the 9/11 attacks in the United States and recent global developments clearly show the growing trend towards the use of weapons in terrorist crimes; 5) there is a real threat that weapons of mass destruction (nuclear, chemical, biological, etc.) may be used in crime.

Below we present the findings of our own social research focused on current problems of weaponology and legal regulation of firearms circulation in Ukraine. They were obtained by surveying more than 200 persons from a certain category of population, including cadets of the Academy of the Ministry of Internal Affairs, secondary school teachers and university students, aged between 17 and 55 .

These findings allow for the following conclusions:

1) only 5\% of the MIA Academy cadets answered "yes", while the rest - 95\% - answered "no" to the first question of the survey, "Is our society ready for free sale of firearms?" Only $4 \%$ of the surveyed secondary school teachers responded positively to this question.

Following the analysis of answers to the first question, it may be concluded that responses from university students differ from those given by the MIA cadets and secondary school teachers $(15 \%$ of the students believe that the public is ready for free sale of firearms, while $85 \%$ think that the opposite is true). Summarized opinion of the respondents shows that our society is still not ready for free sale of firearms.

2) $42 \%$ of the MIA cadets responded positively to the question "How do you feel about buying and carrying a firearm?" This can be explained by the fact that their future occupation is associated with carrying and using firearms. Only $12 \%$ of the teachers responded positively. An explanation to this is that $80 \%$ of teachers are women, and carrying 
weapons is not natural for women. $28 \%$ of the students also responded positively to the question.

3) findings of the survey show that, in response to the question "Does buying a firearm mean the exercise by a person of a right to protect his/her life?", $65 \%$ of the MIA cadets expressed opinion that purchasing a firearm constituted the exercise of a constitutional right to protect one's life. However, $35 \%$ of the cadets think otherwise. The same position is shared by the secondary school teachers, only $20 \%$ of whom support this suggestion, while $80 \%$ are against it. Various reasons could be cited to explain the teachers' attitude. For example, the teachers are opposed to the idea of children below 18 bringing weapons to school. This may affect their outlook, interfere with the process of proper school education, etc.

4) as may be seen from the answers to the question "Do you think that crime rates will increase if free sale of firearms is allowed?", $90 \%$ of the cadets believe that crime rates will increase because of this.

Secondary school teachers believe that the answer to this question may be fifty-fifty. In other words, half of the surveyed teachers think that crime rates will rise because of the higher circulation of weapons, while the other half believe that these rates will drop, since potential offenders will think that the victim might be carrying a weapon that can be used for self-defense. Of the total number of students participating in the survey, only $40 \%$ think that the crime rates will grow, whereas $60 \%$ believe that they will drop. There is no easy explanation to this; perhaps, the students were more concerned with their future than with crime rates.

5) as regards the next question, statistics show that $80 \%$ of the MIA cadets would buy firearms or some other weapons, if free sale of weapons were allowed. Teachers, meanwhile, do not want to do anything with guns. However, $15 \%$ of the surveyed teachers would still buy a firearm for personal use. Perhaps this can be explained by the expectations of these $15 \%$ of the teachers that, with firearms in their possession, they would guarantee themselves self-defense against offenders. The students, $60 \%$ of whom responded positively, believe that this is the only way to protect themselves. The remaining $40 \%$ merely share negative attitude towards guns.

6) when answering the survey question "Please list those categories of persons to 
whom you would prohibit buying a firearm," opinions of the respondents differed, i.e., $9 \%$ believe that mentally ill persons must be prohibited from buying and carrying weapons. 17\% believe that buying a weapon should be prohibited to mentally unstable individuals and to those who are registered with neuropsychiatric dispensaries. $25 \%$ of the respondents would ban selling weapons to persons with drug and alcohol addictions. $18 \%$ of the respondents believe that the sale of weapons must be prohibited to persons released from prison. 11\% believe that such a ban should be extended to incapacitated persons. $20 \%$ of all the respondents believe that selling and carrying guns should be prohibited to everyone, save for those whose professional duties are associated with wearing and using firearms.

It should be noted generally that those were not the only categories of people mentioned in the survey responses. Another category included minors. Only 5\% of all respondents voted in favor of them. Only one respondent suggested that "tear gas weapons should be sold only to those aged 20, while firearms - only to those above 25 years of age, except mentally sick, unstable, incapacitated and other persons."

7) all the respondents split into two categories when answering the question "What kind of weapon do you prefer?"; i.e., with the three groups (the MIA cadets, secondary school teachers, university students) being $100 \%, 80 \%$ spoke in favor of tear gas weapons. This can be explained by the unwillingness of the majority of the respondents to do serious harm to other people when using weapons. The other group, i.e., 20\%, prefer firearms. In other words, they believe that firearms offer more protection.

8) replying to the survey question "What, in your opinion, should be the responsibility for illegal use of weapons?," the majority of the respondents said that illegal use of weapons must be criminalized irrespective of the circumstances or severity of the crime. When answering this question, the teachers (25\%) and students (15\%) expressed the opinion that some other responsibility should be imposed, without going into further details.

Our social research findings lead to the conclusion that our society is not inclined towards free sale and carrying of firearms. The reasons for this are both the specifics of our nation's economic development and a peculiar public mentality.

That is why today, against the background of growing arms trafficking, a significant number of respondents rightly emphasize the need for prosecuting the persons who illegally possess firearms. 
Conclusions Weapons themselves are a source of increased danger; their spread in the society is influenced by various economic, moral and other important factors, to be topped by such key factor as the Law of Ukraine "On Weapons" [15, 16, 17]. Great importance on the part of Ukrainian government authorities and civil-society organizations is attached in this context to the development and implementation of the national doctrine of supporting the security of man, society and the State, as well as to improving the efficiency and effectiveness of legislative, law enforcement and human rights activities.

\section{References}

1. The Constitution of Ukraine. 1996. Kyiv.

2. Bilenchuk P. D., 1999. Legal Status of an Individual. Kyiv: Atyka.

3. Bilenchuk P. D., 1999. The Constitutional Law of Ukraine. Kyiv: Atyka.

4. Bilenchuk P. D., Kofanov A. V., Sulyava O. F., 2003. Ballistics: Forensic Firearms Weaponology. A University Textbook. Kyiv: BeeZone International Agency.

5. Theoretical and Practical Aspects of Arms Trafficking. URL: http://www.intellectualarchive.com/Journal_Files/IAJ_2019_02_011.pdf,

https://doi.org/10.32370/IA_2019_02_11

6. Sulyava O. F., 2003. Use of forensic statistics and information in the investigation of firearms crimes. In: Legal Statistics: Problems of Theory and Practice. An Edited Volume. Khmelnytskyi: The Khmelnytskyi University of Management and Law. pp. 77-82.

7. The 2000 United Nations Convention against Transnational Organized Crime. 2003. Kyiv.

8. Bilokon M. V., Kosohovskyi A. A., 1999. Weapons. In: Police of Ukraine. Nos. 9-10. pp. 18-19.

9. Bilenchuk P. D., Yerkenov S. E., Kofanov A. V., 1999. Transnational Crime: Current Status and Transformation. Kyiv.

10. Guided by Law Only, Upholding the Rights of Hunters. In: Forestry and Hunting Magazine. 2003. No. 2. p. 48.

11. Forestry of Ukraine. A Magazine of the State Forestry Committee of Ukraine. 2003. p. 17.

12. A Methodology for Establishing the Hunting (Sporting) Smooth-bore Shotgun Category of Products. Protocol dated 11/17/1999. Ministry of Internal Affairs and Ministry of Justice of Ukraine. Kyiv.

13. Firearms Identification and Tracing Methods. ATF National Tracing Center (Gun Control Act (GCA) of 1968).

14. Forensic examination of firearms, ammunition and shot traces (forensic ballistics). 
URL: http://elar.naiau.kiev.ua/jspui/handle/123456789/10710

15. Certain International and Criminal Law Aspects of the Use and Circulation of Weapons. URL: https://doi.org/10.32370/IA_2019_09_11

16. Legal regulation of the firearms circulation in the countries of the former Warsaw treaty and the Soviet Union. URL: http://dx.doi.org/10.25313/2520-2308-2019-2-4852

17. Criminal law and forensic classification of smooth-bore firearms. URL: https://doi.org/10.32370/IAJ.2079 